American Journal of Applied Sciences 9 (3): 425-428, 2012

ISSN 1546-9239

(C) 2012 Science Publications

\title{
The Effect of Thyristor Controlled Series \\ Capacitor on Transient Stability of Single Machine Infinite Bus System with the Exact Short Transmission Line Model
}

\author{
Prechanon Kumkratug \\ Division of Electrical Engineering, \\ Faculty of Engineering at Si Racha, Kasetsart University, \\ 199 M. 6, Tungsukhla, Si Racha, Chonburi, 20230, Thailand
}

\begin{abstract}
Problem statement: It is becoming increasingly important to fully utilize the existing transmission system assets due to environmental legislation, rights-of-way issues, costs of construction and deregulation policies that were introduced in recent years. The Thyristor Controlled Series Capacitor (TCSC) has been proposed for better control power flow and dynamic performance. The exact short transmission line model consists of the resistance and reactance. Most of previous researches studies transient stability performance of TCSC in SMIB System while neglecting the resistance of the line. Thus the full capability of the TCSC on transient stability improvement of power system may not be applied. The consideration of the resistance causes difficulty of deriving the mathematical model. Approach: This study investigates the effect of the TCSC on transient stability of the power system with consideration the exact short transmission line mode. The concept of two-port network is applied to simplify the mathematical model of the power system. The proposed method is tested on sample system and compared on various cases. Results: The first swing of rotor angle curve of the faulted system without resistance is obviously higher than that of with resistance whereas the second swing of the faulted system without resistance is slightly less than that of with resistance. The system with a TCSC can improve transient stability of power system. Conclusion: It was found from this study that the TCSC and resistance of the line can improve first swing of rotor angle. However, the resistance of the line provides the negative effect on second swing of rotor angle. The simulation results indicate that for practical short line, the resistance is a very important parameter for evaluating transient stability of power system.
\end{abstract}

Key words: Power system stability, transient stability, critical clearing time, FACTS devices, resistance, reactance, capacitance, transmission line, short transmission line, two-port network

\section{INTRODUCTION}

Nowadays, the demand of electricity has dramatically increased and a modern power system becomes a complex network of transmission lines interconnecting the generating stations to the major loads points in the overall power system in order to support the high demand of consumers. It is becoming increasingly important to fully utilize the existing transmission system assets due to environmental legislation, rights-of-way issues, costs of construction and deregulation policies that introduced in recent years. A number of Flexible AC Transmission System (FACTS) controllers, based on the rapid development of power electronics technology, have been proposed for better utilization of the existing transmission systems (Kumkratug, 2010; Gupta et al., 2010; Osuwa and Igwiro, 2010; Al-Husban, 2009; Magaji and
Mustafa, 2009; Liew et al., 2010; Samikannu and Poonamallie, 2011; Zarate-Minano et al., 2010).

Thyristor Controlled Series Capacitor (TCSC) is the series FACTS devices. It consists of the capacitor bank reactor bank and thyristor. The thyristors control the reactance that dictate the power flow through a line. The TCSC can be applied for improving transient stability of power system.

The evaluation of Critical Clearing Time (CCT) of power system is one of the most important research areas for power engineers because it indicates the robustness of the faulted power system. The rotor angle of the synchronous generator determines the stability of power system. Although the stability of the synchronous machine is used to represent the stability of the power system, all of the power system components such as transmission line and transformer affect the stability of the power system. 
Am. J. Applied Sci., 9 (3): 425-428, 2012

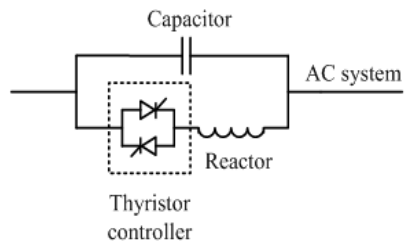

Fig. 1: Schematic diagram of TCSC

The transmission line is one of the most important parts in power system components. Most of the fault occurs at the transmission line. It is generally divided into three major categories; short, medium and long model whose distance are about $80 \mathrm{~km}$, above $80-250 \mathrm{~km}$ and above $250 \mathrm{~km}$, respectively. Many previous researches used simple transmission line model by neglecting its resistance or capacitance. To fully utilization the existing system, the exact transmission line should be further investigated.

This study will investigate the capability of the TCSC on transient stability of the SMIB system with the exact short transmission line model. The concept of two-port network is applied to simplify the mathematical model of the power system. The sample system consisting the practical short transmission line is used to investigate in this study. The proposed method is tested on various cases (Fig. 1).

\section{MATERIALS AND METHODS}

Mathematical model: Figure 2a shows the single line diagram of power system consisting of a generator, a transformer, four short transmission lines and TCSC. Figure $2 b$ shows the equivalent of Fig. $2 a$. The generator is represented by a synchronous voltage in quadrature axis $\left(\mathrm{E}_{\mathrm{q}}^{\prime}\right)$ behind direct transient reactance $\left(\mathrm{X}_{\mathrm{d}}{ }_{\mathrm{d}}\right)$. The $\mathrm{V}_{\mathrm{b}}$ is the voltage at infinite bus. The exact short transmission line model is represented by the impedance $\left(\mathrm{Z}_{\mathrm{L}}\right)$ which consists of a resistance $\left(\mathrm{R}_{\mathrm{L}}\right)$ and reactance $\left(\mathrm{X}_{\mathrm{L}}\right)$. The TCSC can be modeled as the variable series reactance $\left(\mathrm{X}_{\mathrm{TCSC}}\right)$ as shown in Fig. 2b. This study will apply the concept of the twoport network to simplify the equivalent in Fig. 2b. Each component of power system and a TCSC can be represented the matrix of two-port networks (A, B, C and D) as shown in Fig. $2 \mathrm{c}$ and given by Eq. 1-8:

$$
\begin{aligned}
& \mathrm{A}_{1}=\mathrm{A}_{2}=\mathrm{A}_{3}=\mathrm{A}_{4}=\mathrm{A}_{5}=\mathrm{A}_{6}=\mathrm{A}_{\mathrm{TCSC}}=1 \\
& \mathrm{~B}_{1}=\mathrm{j} \mathrm{X}_{\mathrm{d}}^{\prime} \\
& \mathrm{B}_{2}=\mathrm{jX_{ \textrm {t } } ^ { \prime }} \\
& \mathrm{B}_{3}=\mathrm{B}_{4}=\mathrm{B}_{5}=\mathrm{B}_{6}=\mathrm{j} \mathrm{Z}_{\mathrm{L}}
\end{aligned}
$$

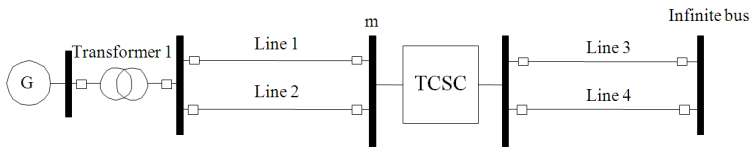

(a)

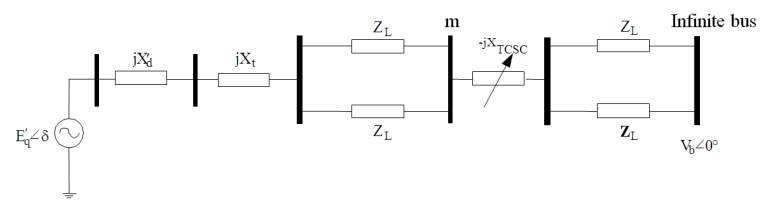

(b)

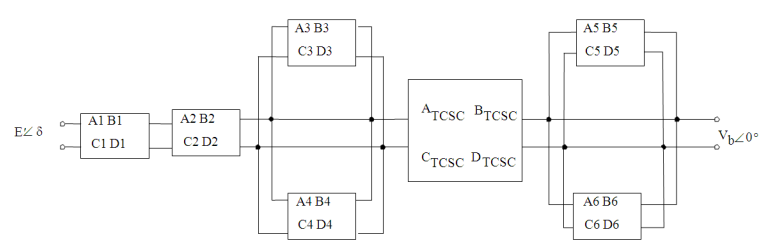

(c)

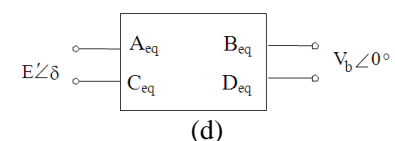

Fig. 2: Single machine infinite bus system with consideration of the exact short line model (a) schematic diagram (b) equivalent circuit (c) two port networks diagram (d) the net two-port network

$\mathrm{B}_{\mathrm{TCSC}}=-\mathrm{j} \mathrm{X}_{\mathrm{TCSC}}$

$\mathrm{C}_{1}=\mathrm{C}_{2}=\mathrm{C}_{3}=\mathrm{C}_{4}=\mathrm{C}_{5}=\mathrm{C}_{6}=0$

$\mathrm{C}_{\mathrm{TCSC}}=0$

$\mathrm{D}_{1}=\mathrm{D}_{2}=\mathrm{D}_{3}=\mathrm{D}_{4}=\mathrm{D}_{5}=\mathrm{D}_{6}=\mathrm{D}_{\mathrm{TCSC}}=1$

It can be seen from the Fig. $2 \mathrm{c}$ that some ports are in series and in shunt connection. For example, a port 1 and port 2 are in series connection whereas port 3 and port 4 are in shunt connection. Thus with the series combination of port 1 and port 2, a new port is given by Eq. 9-12:

$$
\begin{aligned}
& \mathrm{A}_{\mathrm{s}}=\mathrm{A}_{1} \mathrm{~A}_{2}+\mathrm{B}_{1} \mathrm{C}_{2} \\
& \mathrm{~B}_{\mathrm{s}}=\mathrm{A}_{1} \mathrm{~B}_{2}+\mathrm{B}_{1} \mathrm{D}_{2} \\
& \mathrm{C}_{\mathrm{s}}=\mathrm{A}_{2} \mathrm{C}_{1}+\mathrm{C}_{2} \mathrm{D}_{1} \\
& \mathrm{D}_{\mathrm{s}}=\mathrm{B}_{2} \mathrm{C}_{1}+\mathrm{D}_{1} \mathrm{D}_{2}
\end{aligned}
$$

Similarly, with the shunt combination of port 3 and port 4, a new port is given by Eq. 13-16: 
Am. J. Applied Sci., 9 (3): 425-428, 2012

$\mathrm{A}_{\mathrm{sh}}=\left(\mathrm{A}_{3} \mathrm{~B}_{4}+\mathrm{A}_{4} \mathrm{~B}_{3}\right) /\left(\mathrm{B}_{3}+\mathrm{B}_{4}\right)$

$\mathrm{B}_{\mathrm{sh}}=\mathrm{B}_{3} \mathrm{~B}_{4} /\left(\mathrm{B}_{3}+\mathrm{B}_{4}\right)$

$\mathrm{C}_{\mathrm{sh}}=\mathrm{C}_{3}+\mathrm{C}_{4}+\left(\mathrm{A}_{3}-\mathrm{A}_{4}\right)\left(\mathrm{D}_{4}-\mathrm{D}_{3}\right) /\left(\mathrm{B}_{3}+\mathrm{B}_{4}\right)$

$\mathrm{D}_{\mathrm{sh}}=\left(\mathrm{B}_{4} \mathrm{D}_{3}+\mathrm{B}_{3} \mathrm{D}_{4}\right) /\left(\mathrm{B}_{3}+\mathrm{B}_{4}\right)$

With the above concepts, the net two-port network diagram is shown in Fig. 2d. Here $A_{\text {eq }}, B_{\text {eq }}, C_{\text {eq }}$ and $D_{\text {eq }}$ are the element in net matrix of net two-port networks.

The output electrical power of synchronous machine $\left(\mathrm{P}_{\mathrm{e}}\right)$ Eq. 17:

$P_{e}=\frac{A_{\text {eq }}\left(E_{q}^{\prime}\right)^{2}}{B_{\text {eq }}} \cos \left(\theta_{\text {Beq }}-\theta_{\text {Aeq }}\right)-\frac{\mathrm{V}_{\mathrm{b}} E_{q}^{\prime}}{B_{\text {eq }}} \cos \left(\theta_{\text {Beq }}+\delta\right)$

Here:

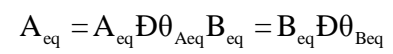

The dynamic equation for evaluating critical clearing tine of the system in Fig. 2a is given by:

$\dot{\delta}=\omega$

$\dot{\omega}=\frac{1}{\mathrm{M}}\left[\mathrm{P}_{\mathrm{m}}-\mathrm{P}_{\mathrm{e}}\right]$

Here, $\delta, \omega$ and $\mathrm{P}_{\mathrm{m}}$ as given in Eq. 18-19 are the rotor angle, speed, mechanical input power and moment of inertia, respectively of synchronous machine. The $\mathrm{P}_{\mathrm{e}}$ is the output electrical power of synchronous as given in Eq. 15.

It can be mentioned here that the variable series reactance of the TCSC as given in Eq. 7 is changed during the dynamic state for improve the transient stability. This study uses the linear control given by Eq. 20:

$\mathrm{X}_{\mathrm{TCSC}}=\mathrm{K} \omega$

Here $\mathrm{K}$ is the constant gain control.

\section{RESULTS}

Consider the diagram of sample system is shown in Fig. 1a. The system data are:

$\mathrm{H}=5, \mathrm{X}_{\mathrm{t}}=0.1 \mathrm{pu}, \mathrm{X}_{\mathrm{d}}=0.20 \mathrm{pu}, \mathrm{X}_{\mathrm{L} 1}=0.5 \mathrm{pu}, \mathrm{X}_{\mathrm{L} 2}=$ $0.5 \mathrm{pu}, \mathrm{X}_{\mathrm{L} 3}=0.5 \mathrm{pu}, \mathrm{X}_{\mathrm{L} 4}=0.5 \mathrm{pu}, \mathrm{E}_{\mathrm{q}}=1.22<31.64 \mathrm{pu}$, $\mathrm{V}_{\mathrm{b}}=1 \mathrm{pu}$

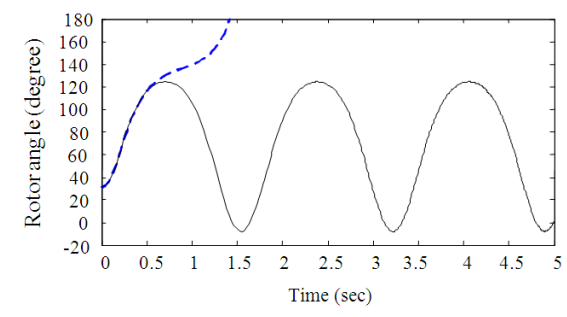

Fig. 3: Swing curve of the system without FACTS devices and $\mathrm{R} / \mathrm{X}=0$ and $\mathrm{R} / \mathrm{X}=5 \%$ for $\mathrm{tcl}=191 \mathrm{~m} \mathrm{sec}$

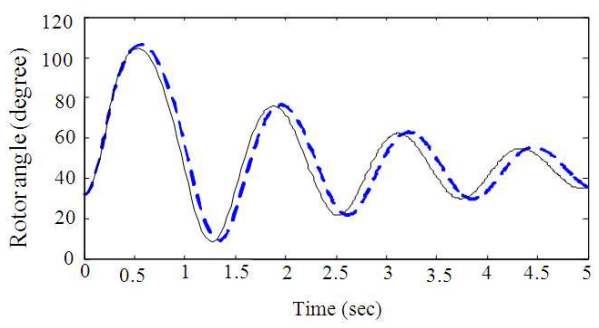

Fig. 4: The rotor angle for $\mathrm{tcl}=191$, with $\mathrm{K}=10$, $\mathrm{R} / \mathrm{X}=0, \mathrm{R} / \mathrm{X}=5 \%$

Table 1: The maximum and minimum rotor angle of the system with various gains of TCSC

\begin{tabular}{lccccc}
\hline & & \multicolumn{2}{c}{$\boldsymbol{\delta}_{\max }($ degree $)$} & \multicolumn{2}{c}{$\boldsymbol{\delta}_{\min }($ degree $)$} \\
\multicolumn{1}{c}{ Case } & $\mathrm{K}$ & $\mathrm{R} / \mathrm{X}=0$ & $\mathrm{R} / \mathrm{X}=5 \%$ & $\mathrm{R} / \mathrm{X}=0$ & $\mathrm{R} / \mathrm{X}=5 \%$ \\
\hline 1 & 0 & - & 124.65 & - & -7.65 \\
2 & 10 & 106.04 & 104.44 & 9.12 & 8.65 \\
3 & 20 & 95.79 & 94.75 & 20.45 & 19.22 \\
4 & 30 & 87.76 & 87.07 & 27.81 & 26.45 \\
5 & 40 & 81.63 & 81.20 & 33.05 & 31.56 \\
6 & 50 & 76.78 & 76.45 & 36.78 & 35.32 \\
\hline
\end{tabular}

Table 2: The maximum and minimum rotor angle of the system with various $\mathrm{R} / \mathrm{X}$ ratio for $\mathrm{K}=35$

\begin{tabular}{lccc}
\hline Case & $\mathrm{R} / \mathrm{X}(\%)$ & $\delta_{\max }($ degree $)$ & $\delta_{\min }($ degree $)$ \\
\hline 1 & 0 & 83.64 & 29.21 \\
2 & 5 & 83.29 & 29.36 \\
3 & 10 & 82.84 & 29.25 \\
4 & 15 & 82.57 & 29.13 \\
5 & 20 & 82.53 & 29.07 \\
6 & 25 & 82.58 & 29.01 \\
\hline
\end{tabular}

It is considered that three phase fault appears at line 1 near bus $\mathrm{m}$ and the fault is cleared by opening circuit breakers at the end of the line. Figure 3 shows the rotor angle of the system without a TCSC $(K=0)$ for the clearing time $\left(\mathrm{t}_{\mathrm{cl}}\right) 191 \mathrm{msec}$. The break line represents the rotor angle of the system without consideration of line resistance $(\mathrm{R} / \mathrm{X}=0)$ whereas the dash line represents the rotor angle of the system with $\mathrm{R} / \mathrm{X}=5 \%$ whereas the Fig. 4 shows the rotor angle of the system with a TCSC $(K=10)$. Table 1 shows the comparisons of the system with $\mathrm{R} / \mathrm{X}=0 \%$ and $\mathrm{R} / \mathrm{X}=$ 
$5 \%$. In this case the constant gain control is changed. Table 2 summarizes the maximum and minimum rotor angle of the system $\left(\delta_{\max }, \delta_{\min }\right)$ with various $\mathrm{R} / \mathrm{X}$ ratio for $\mathrm{K}=35$.

\section{DISCUSSION}

It can be seen from the Fig. 3 that resistance of the line provides the improvement of the first swing stability. With the $\mathrm{R} / \mathrm{X}=0$, the system is considered as unstable whereas with the consideration of $\mathrm{R} / \mathrm{X}=5 \%$, the system is stable. However, the resistance of the line provides the negative effect of the second swing as can be seen in Fig. 4 and the Table 1 . With $\mathrm{K}=30$, the $\delta_{\max }$ of the system with $\mathrm{R} / \mathrm{X}=0 \%$ and $5 \%$ are 27.81 and 26.45 , respectively. The effect of various ratios $\mathrm{R} / \mathrm{X}$ and a TCSC $(\mathrm{K}=35)$ on transient stability improvement is summarized on Table 2. It can observe from the Table that the better improvement results are increased as the percent of $\mathrm{R} / \mathrm{X}$ gets increase.

\section{CONCLUSION}

This study investigated the effects of the Thyristor Controlled Series Capacitor (TCSC) on transient stability improvement of the Single Machine Infinite Bus (SMIB) system with the consideration of the resistance of the transmission line. The mathematical model was systematically derived by using the concept of the two-port network. This concept can help us to obtain mathematical model of the system in the simpler way.

The presented methods were tested and compared on various cases. It was found from the simulation results that the TCSC improve the transient stability performance both first swing stability and other swings whereas the resistance of the line provides the improvement of the first swing but not for the second swing.

\section{REFERENCES}

Al-Husban, A.N., 2009. An eigenstructure assignment for a static synchronous compensator. Am. J. Eng. Applied Sci., 2: $\quad 812-816 . \quad$ DOI: 10.3844/ajeassp.2009.812.816

Gupta, P.D., N.C. Majee and A.B. Roy, 2010. Stability analysis of a class of three-neuron delayed cellular neural network. OnLine J. Biol. Sci., 10: 36-43. DOI: 10.3844/ojbsci.2010.36.43

Kumkratug, P., 2010. Application of interline power flow controller to increase transient stability of power system. J. Comput. Sci., 6: 1490-1493. DOI: 10.3844/jcssp.2010.1484.1487

Liew, S.Y., E.S.K. Wong and C.K. Fatt, 2010. Advanced information technology of slotswitching network schemes for on all-optical variable-length packet. J. Comput. Sci., 6: 1-11. DOI: $10.3844 /$ jcssp.2010.1.11

Magaji, N. and M.W. Mustafa, 2009. Optimal thyristor control series capacitor neuro-controller for damping oscillations. J. Comput. Sci., 5: 983-990.

Osuwa, J.C. and E.C. Igwiro, 2010. Uninterruptible power supply using solar rechargeable battery. Phys. Int., 1: 77-82. DOI: 10.3844/pisp.2010.77.82

Samikannu, R. and B.A. Poonamallie, 2011. Design of synthetic optimizing neuro fuzzy temperature controller for dual screw profile plastic extruder using labview. J. Comput. Sci., 7: 671-677. DOI: 10.3844/jcssp.2011.671.677

Zarate-Minano, R., T.V. Custsem, F. Milano and A.J. Conejo, 2010. Securing transient stability using time-domain simulations within an optimal power flow. IEEE Trans. Power Syst., 25: 243-253. DOI: 10.1109/TPWRS.2009.2030369 